\title{
Neo-Ottomanism - Emergence, Ideology and Political Doctrine
}

\author{
Ivaylo Hristov \\ University of National and World Economy, Sofia
}

\begin{abstract}
This paper aims to examine the conceptual platform and political doctrines of neo-Ottomanism. In particular, the text aims to study the essence and positioning of neo-Ottomanism, its emergence and gradual assertion against the backdrop of the Turkish elite's doctrines that have taken shape throughout history, mostly at the contemporary stage of the decline of the Kemalist ideology. The paper holds the view that neoOttomanism is the validating ideology and policy of the new class of entrepreneurship in Turkey, which since the end of Cold War I has been relying on its new economic power, accumulated capital and military supremacy in the region in its attempt to expand its role in international relations. This policy is an attempt to combine values that are incompatible in essence, character and content. In particular, this means that the new ideology, which revives Islamism, aims to get incorporated within the political system of the secular state, and the final result is the Islamization of statehood; the ideology of neo-Ottomanism adheres to the Kemalist slogan of 'zero problems' with the neighbouring states, yet from the perspective of 'strategic depth', it inevitably leads to a political and possibly military expansion, which in turn ultimately gives rise to the contemporary form of revanchism (foreign policy aimed at revenge and regaining lost territories); the neo-Ottomanist ideology adheres to its 'Western orientation', displaying its aspirations at freeing Turkey from its dependence on the United States, which basically constitutes a claim for taking on the role of a global leader.
\end{abstract}

\section{INTRODUCTION}

In today's democratic world there has been enhanced interest toward the ideology and political practices of neo-Ottomanism. This is the case because its doctrines are increasingly becoming the official poli-

Social Evolution \& History, Vol. 18 No. 1, March 2019 139-156

(C) 2019 'Uchitel' Publishing House

DOI: $10.30884 / \mathrm{seh} / 2019.01 .08$ 
cy of the Republic of Turkey. What is more, the ambitions of neoOttomanism have caused concern in South-Eastern Europe, where there are vivid reminiscences of the Ottoman Empire that existed between the fourteenth and the twentieth centuries. Even though history's assessments of this empire have been fairly controversial, it cannot be denied that it constitutes a specific kind of caliphate that is organized in the spirit of Islamic theology. As a result of this model of social organization, some peoples have slowed down and accordingly lagged behind in their development. In the twenty-first century attempts have been registered at transforming Islam from a religion into an ideology and policy, which precipitated the establishment of a geopolitical paradigm that overrides all values lying at the heart of the European civilization.

The rise of neo-Ottomanism as an ideology and policy in Turkey is attributed to the Party of Justice and Development (Adalet ve Kalkinma Partisi, AKP), set up in 2001 by Recep Erdogan, the former mayor of Istanbul.

The party became the ruling party in Turkey in April 2007. Since then most of the time the party has enjoyed an absolute majority in parliament. In November 2015, its leaders called an early general election and the party won 316 out of the 550 seats in parliament. The Party of Justice and Development has been openly pursuing a policy of neo-Ottomanism. Its rise puts forward the question of the crisis of the European system of values. In particular the question of why, despite the widely held view that it is the supreme accomplishment of human civilization, is there not any evidence showing that this system is being embraced by other cultures? The outcome of the so-called Arab Spring is proof of this. Instead of celebrating democracy (as expectations were), Islamists have taken the upper hand. A serious challenge is the fact that the citizens of Europe have embraced the ideas of radical Islam. In this context, there is a pressing need to reconsider the European concept for holding a multicultural and multi-religious dialogue, and neo-Ottomanism is an indispensable part of this dialogue.

\section{THE IDEOLOGY OF CONTEMPORARY} NEO-OTTOMANISM IN A HISTORICAL PERSPECTIVE

In a historical perspective, neo-Ottomanism is grounded in the official ideologies and practices of the former Ottoman state from both the classical and later stages of development. Neo-Ottomanism has taken on the major role in these stages. Its core idea pertains to the unification of all ethnic communities, regardless of their ethnic origin or religious affiliation, for the sake of preserving the Ottoman state as a pre- 
requisite to ensure the prosperity of its subjects. The doctrine of Ottomanism is revealed to the utmost in the documents from the Tanzimat era, which in turn precipitated the reforms carried out in the twentieth century. Of particular relevance is Gülhane Hatt-i-Sherif issued by Sultan Abdulmejid (1839-1861) on November 3, 1839. He pursued three major goals on his agenda: providing for the security, life, integrity and property of all his subjects, regardless of their religious affiliation and national identity; the fair collection and allocation of taxes, the introduction of rules and regulations guiding the recruitment of servicemen in the army, as well as the length of military service (Fadeeva 1985: 57). The Sultan's decree for the first time identified the need to establish an army in which servicemen are recruited from all over the country and among all social strata. This was an important part of the doctrine of the newly emerging Ottomanism. This was the doctrine for the unified society ruled by the Ottoman Dynasty (Osmanli in Turkish), where rights were in line with duties. Guaranteeing the life, integrity and property of all subjects, regardless of their religion or affiliation to a religious sect, was declared as being sacred, that is, complying with the Muslim laws (Fadeeva 1985: 58).

The second period of the Tanzimat was launched with the adoption of Hatt-i-Humayun in 1856. It was developed by Ali Pasha and with the participation of English and French ambassadors. A number of provisions laid down in the Gulhan Hatt-i-Sheref are further developed and clearly differentiated in the new decree. Yet there were serious obstacles during the implementation of this project. These involved the unabating clashes of the interests of Muslims and Christians amid the emergence of their economic and cultural life. They were further expressed in the deepening conflicts within the Christian and Muslim communities, which subsequently shaped the national identity of the Serbs, Bulgarians, Romanians, as well as of the Arabs, Albanians and other peoples that inhabited the Ottoman Empire (Fadeeva 1985: 65).

The two documents were the first attempts at modernizing the Turkish institutions in a European fashion. This process constituted an administrative reform conducted in the top-bottom mode. The ruling circles became aware of the need for this reform and even the most fervent conservatives did not dare deny it. Hence the modernization of the Ottoman Empire became an irreversible process. In practice its existence was possible on the basis of the equality of all the peoples living in the empire, while political power remained in the hands of the Turks. All subjects were granted access to posts in government, provided that they had the respective capabilities and skills, knowledge of the Turkish language and showed loyalty to the empire, irrespective of their reli- 
gious affiliation (Fadeeva 1985: 95). Despite the declared intentions, most reforms remained within the realm of wishful thinking. After all, they were not embodied in a constitution, nor did they involve the creation of a parliament, holding elections and the establishment of political parties or civil society. Overall, they were not meant to change the status quo. The Tanzimat-related reforms did not in any way restrict the Sultan's power. Despite expectations that Muslims and non-Muslims will enjoy equal rights, this did not happen to the fullest. In any case, however, the changes opened up the opportunity for the peoples in submission to be entitled to appointment to important positions in the empire's economic and political life.

During the second half of the nineteenth century, the young Ottoman intelligentsia started launching ideas and conceptions envisaging the transformation of the Ottoman Empire into a constitutional monarchy. The young Ottomanists shared the ideas and values of the West, and believed that the tansimus leaders were of a specific social and professional background. Yet, they criticized its oligarchic elite for the fact that it had embraced only some superficial aspects of the Western culture instead of adopting its political institutions and principles. As a result of the efforts the neo-Ottoman movement ('The society of the new Osmanli') put into reforming the Turkish society, the first constitution in Turkey's history was pronounced (on 23 December 1876 in Tsargrad [Constantinople]). The constitution of 1876, inspired by Mithat Pasha, both synthesizes and tests the young Ottomanists' understanding of Ottomanism. Basically this document was the first attempt made in the Ottoman Empire at creating the basic law. Mithat Pasha's project resulted in the establishment of a bicameral parliament (general assembly and senate), which was a genuine attempt at democratizing the Turkish society. However, members of the parliament had no right to vote or table legislative motions. At elections there were no political parties, nor a majority in parliament to form a government. In practice it was the Sultan who appointed the Grand Vizier, who in turn nominated the ministers, and the latter were subsequently appointed by the Senate. Despite its grand ambitions, Mithat's Constitution did not provide for the establishment of a parliamentary democracy. The Oriental political system remained in place, while Mithat's 'constitutionalism' was rather seen as an attempt to adapt the values of the European parliamentary democracy to the traditions of the Islamic society. The limited social base, as well as the impotence and the lack of political experience on the part of the newly emerging national bourgeoisie were the reasons for the defeat of the New Ottomanist constitutional movement by Sultan Abdul Hamid II. Nevertheless, the 
fact that Constitution was pronounced, albeit for a short period of time until 1878, comprised a decisive step in the modernization of the Turkish society, bringing it in line with the European standards.

Contemporary neo-Ottomanism is also based on the ideologies of pan-Islamism and pan-Turkism.

As a doctrine, pan-Islamism emerged in the 1870s and 1880s and was one of the attempts at preventing the demise of the Ottoman Empire. Pan-Islamism holds the view of ensuring solidarity of the peoples from the Muslim countries and their integration within a unified and powerful Islamic empire. In compliance with this concept, the empire should encompass the Muslims (including those of non-Turkish origin) from the Middle East, North Africa, Afghanistan, Russia, the Caucasus, Iran and Egypt, among other countries. Pan-Islamism does not recognize any national distinctions and specific features of the Muslim peoples. It engages in canvassing 'the unity and brotherhood of Muslims', foisting on them an artificially created 'Ottoman language'. As an ideological and political movement, pan-Islamism picked up pace during the rule of Sultan Abdul Hamid II, who used it as a tool to curb the influence of pan-Slavism and Russia in the Balkans and to weaken 'the new Ottomans' and eliminate them from the political life (Hakov 2010: 18). Pan-Islamists saw as the major reason for the decline of the Ottoman Empire its propensity to imitate the West and its destructive actions under the regime of capitulations. Their major opponents are the representatives of the so-called Westernization. As a strategy for the development of the Ottoman state, the latter emerged as the Movement of 'the new Ottomanists' in the $1860 \mathrm{~s}$. Its proponents called for the adoption of the Western social and cultural institutions and technologies as a tool to save the Ottoman Empire. Pan-Islamists did not basically deny the modernization of the Turkish society, but were against the blind imitation of the West European identifiers. They did not embrace the idea that European civilization was the supreme accomplishment of mankind. Despite its broad scope as a concept, panIslamism was never implemented and remained within the realm of the dream for Muslims' unification that failed to materialize.

Turkism, which was subsequently revived as pan-Turkism, is a form of the belatedly emerged Turkish nationalism. It originated in the early twentieth century, when it became evident that Ottomanism and panIslamism could not possibly prevent the decline of the Ottoman Empire. According to the ideologists of pan-Turkism, it is called upon to unify and rule the 'enormous Turkish world', comprised of 'the Turkic peoples living on the territory of a number of countries across Europe, Africa and Asia. That is to say that it called for the integration 
into a single state of all Turkic peoples, living on a territory spanning across China to the Adriatic region. Pan-Turkism should be credited basically for conceptualizing the idea and defining the notion of a strong and independent Turkish nation. There was no Turkish national identity before the disintegration of the Ottoman Empire. This was determined by the fact that the religious foundation of the Ottoman state ruled out any option whereby an individual could possibly express his Turkish identity and sense of belonging to the Turkish nation. The writer and political activist Ziya Gokalp has a significant contribution to strengthening the ideology of pan-Turkism. He laid down his political and philosophical views in the Principles of Turkism, History of Turkish Civilization, Islamization, among other works. In these works, Ziya Gokalp substantiates the idea of the integration of all Turkiclanguage peoples into a new Ottoman Empire under the leadership of the future Grand Turkey. In essence pan-Turkism provides for the conception of a new Turkish ideal aimed at restoring the selfconfidence of the Turkish people. Even though pan-Turkism failed in its attempts to offer an effective alternative for saving the empire, some of its messages provide the basis for the construction of the new political and ideological philosophy, including those pertaining to Kemalism and neo-Ottomanism.

The collapse of the Ottoman Empire brought about the creation of the Turkish nation, which is a relatively 'young' nation. The ethnic Turkish communities that were living in the territory of Anatolia and part of East Thrace and had largely acquired the Turkish identity were gradually transformed into a nation after the defeat of the Ottoman Empire during World War I. It was in the context of this defeat that Ottomanism and pan-Turkism, which were until then the dominant ideologies, lost their social relevance and authority. This provided the breeding ground for the new nationalist ideology of Kemal Ataturk. This ideology unites the proactive and nationalist-minded circles of the Turkish military officers and of the local Turkish bourgeoisie. In this period, significant parts of the Ottoman Empire were occupied by the central powers that had won a victory in World War I. ${ }^{1}$ Greece launched a military invasion of the Ottoman lands in Asia Minor. The Ottoman Dynasty displayed behaviour of inertia and passivity. The nationalistminded political elite in Turkey organized the masses of Turkish people to an armed resistance to the Greek invasion, the colonial powers and the Ottoman dynasty. This marked the onset of the transformation of the Turkish people into a Turkish nation (Naydenov 2017: 523-532).

By World War II the young nation had been successfully constructed. After World War II, Turkey became a member of NATO. 
The capitalist production mode was gaining ground. This resulted in a population explosion. This explosion, together with some geopolitical 'considerations', encouraged the inflow of western European and American capital and the serious investments in Turkey's economy made during the last decades of the twentieth century. Turkey developed a multi-industrial economy and established a powerful military and industrial complex. It managed to maintain high rates of economic growth. This gives The Economist the reason to refer to Turkey as 'Europe's China'.

Neo-Ottomanism suggests a radical transformation of the Turkish state's domestic political system and its foreign policy priorities: 'NeoOttomanism's goal was that Turkey becomes a leader state, and a regional and global power. It is a multi-dimensional doctrine with global coordinates (the United States, the European Union, Russia, and China) and regional dimensions (the Caucasus, the Middle East, and the Balkans), which is based on a pragmatic ideology, ambitious plans and priorities' (Petrov 2015: 25). The essence of this large-scale geopolitical strategy has been outlined in Ahmet Davutoglu's book 'Strategic Depth', with a subheading 'Turkey's place in international relations' (Davutoglu 2015). In essence, the neo-Ottomanism has gained ground as the ideology and policy of the new Turkish class of entrepreneurs which, since the end of the Cold War, has been relying on its new economic power and accumulated capital, and its military supremacy in the region to expand its role in international relations. Even though Turkey has so far adhered to the global policy of the United States and NATO, the country has set its own strategic goals alongside the promotion of its Euro-Atlantic interests. ${ }^{2}$ It is no coincidence that in a speech delivered to the diplomatic corps in Turkey in January 2010, Ahmet Davutoglu said that Turkey's overambitious goal was that the country be transformed into a world power, not only a regional one. He pointed out that the country enjoyed such prospects due to its geographic location, history and experience in diplomacy. Apparently, this was an attempt by Turkey to distance itself from the United States. This attempt was prompted in the first place by the collapse of the unipolar world. At the beginning of the twenty-first century, the world is increasingly becoming multipolar, and the countries are aspiring to become the agent and not the target of political practices. Hence the polar forces that have an independent role in geopolitics and geo-economics have been multiplying. These are Japan, China, India, Russia and Germany, around which the European Union has gravitated. The next reason for cooling the relations with the United States is the latter's support for the Kurds, a fact that is causing 
serious concerns in Turkey. Therefore neo-Ottomanism is seen as a covert form of anti-Americanism. Imperial ambitions inevitably have an element of anti-Americanism. Back at the turn of the new millennium, when Ahmet Davutoglu's book was published, it contained the elements of anti-Americanism. This trend was due to the fact that Turkey's real economic and military power was disproportionate to the country's negligible rights to decision making in the event of international conflicts. It was before Ahmet Davutoglu wrote 'Strategic Depth' that the Turkish political elite showed signs it would no longer submit to its subordinate role. The invasion of one-third of Cyprus was categorical evidence to this fact. No less convincing proof of the resistance to the US influence have been the ongoing attempts at liquidating the Hizmet Movement (which is most probably standing behind Ergenekon) inspired by the Islamist preacher Fethullah Gulen, who lives in Pennsylvania and works for the CIA. The attempts involve cases of the firing and detention of military officers connected with the United States. Back in 2013, Washington no longer saw Erdogan as a reliable partner. As a result, the American Government carried out a number of operations targeted at Turkey and personally at Erdogan. These include the following: in May-June 2013 the US government inspired and supported the massive street protests held in the Taxim park in Istanbul; during the 2015 general elections CIA financed the Peoples' Democratic Party (HDP), the party of the national minorities, while the terror act committed in 2016, fuelled the discontent among the Kemalist militaries in the army, who made an attempt at coup d'état.

Hence the ideology and policy of neo-Ottomanism is an expression of the newly emerged Turkish elite's refusal to play the role of the 'obedient performer' of the decisions made by the Anglo-Saxon and Jewish political elite of the United States (a case in point is the conflict between Turkey and Israel over the 'Freedom fleet of the Gaza Strip' in 2010). ${ }^{3}$ Neo-Ottomanism further embodies the imperial ambitions cherished by the Turkish elite. After all, as any national bourgeoisie, the Turkish one has the ambitions to expand its economic influence in both neighbouring countries and more distant lands. It therefore needs a guarantee for the security of its investments. Such a guarantee is the political and military power of its state. The interests of the new Turkish bourgeoisie and its aspirations toward feeding on the Islamist enclaves on the territories of the former Ottoman Empire as the pillars of its economic expansion are an important factor for the reaffirmation of the ideology of neo-Ottomanism in present-day Turkey. This vision has historical grounds. What is particularly relevant for neo-Otto- 
manism is the assumption that the 500-year rule of the Ottoman Turks is the longest period of stability and unity in the Balkans, a region ridden by fierce clashes which until the fifteenth century. Ahmet Davutoglu deems the Ottoman rule as the most successful period in the history of the Balkan peoples, considering that the Ottoman Empire guaranteed the peace and security of its subjects compared to other empires and monarchies. It is a different matter whether such an assumption can be regarded as true. In any case the contemporary science does not offer an unequivocal assessment of the centuries-long Ottoman rule in the Balkans, while in their collective memory Balkan peoples themselves share a negative view of this period (Georgieva 1999: 43).

\section{THE EMERGENCE OF NEO-OTTOMANISM}

Neo-Ottomanism did not emerge out of the blue. According to Darko Tanaskovic, some ten years after the death of Kemal Ataturk (on November 11, 1938), his secular nationalist ideology started eroding, while Islamism started reviving. There was a gradual process of re-Islamization of the Turkish society. 'No one even mentions neo-Ottomanism, though it is functional in practice' (Tanaskovic 2010: 27). No matter how strange it may sound, the reason for the onset of the reIslamization of the Turkish society, which lies at the heart of the ideology of neo-Ottomanism, in the post-World War II period is that the Turkish political elite had adopted the western multi-party system (1946), joined NATO (1952) and had become dependent on the Turkish people's outlook, identity, attitudes and preferences, which are strongly connected with the Muslim religion. This created the conditions for some of the political elite's fractions to capitalize on Muslim attitudes and widely held public views so as to attract voters in their struggle for power during general elections. Darko Tanaskovic argues that

[t]he democratization of the Muslim countries in line with the Western standards sooner or later brought to power proIslamist parties, given that in none of these countries, even in Turkey which was a largely secularized country with a constitution, had Islam lost its status of being the fundament of the people's personal and collective identity and in the deeply rooted system of values that determines the direction of public life (Tanaskovic 2010: 28).

Since the introduction of the pluralistic political system, elections have been normally won by political parties that were in opposition to the Kemalist ideology. This stems from the policy of the Turkish state. 
Darko Tanaskovic points out during the mandate of Menderes, who was brought to power in the 1950s as a result of elections, religion was reinstated as a subject taught first in primary and later on in secondary schools, new mosques were constructed, schools for imams and preachers were opened, and powerful dervish orders resumed their influence in public life. In 1960, the rise of Islamism was temporarily brought to a halt after a military coup. Yet after the first post-coup general election, Suleiman Dimerel's Party of Justice regained power and continued, albeit covertly, the process of re-Islamization. In 1971, the military yet again carried out a coup d'etat. Yet the electoral system allowed for Islamist parties' participation in government. In 1980, there was yet another coup d'etat. This time, however, the coup was already stripped of some of its secular motives. The capabilities of Kemalism to counteract Islamism were declining. After this coup, the Islamist religion became a compulsory subject taught at school. An abundance of religious literature was published. In the sphere of arts - cinema, television, novels, poetry, among other arts - there appeared a marked interest in the Ottoman history and in the grandeur of the Ottoman Empire. Some of the 'pillars' of the neo-Ottomanist ideology, such as the idea for 'the Turkish-Islamist synthesis', gained solid ground. The assumption was that Turkey can become a modern nation-state while preserving its Islamist identity.

It was in the 1980s that neo-Ottomanism took shape as an ideology and a political practice. The prominent Turkish politician Turgut Özal (who was prime minister and subsequently president) played a significant role in its reaffirmation in Turkey. Özal managed to win the trust of the US Anglo-Saxon and Jewish elites with his loyalty to them and to NATO, as well as with his liberal economic reforms. Hence he was allowed to take up the careful and consistent revival of the Islamist values, as the United States believed the restoration of moderate traditional Islam in Turkey would act as a hindrance to the penetration of the fundamentalist Islam. Turgut Özal was the first Turkish president to take part in the Hajj pilgrimage to Mecca (in 1983). During his term in office, he relied on Turkey's serious economic achievements and defense capabilities and gradually 'reduced' and curbed the country's subservience to the United States. During his mandate, the Turkish elite launched an open debate on the need for the Turkish nation to take on the responsibility to address the issues of the Islamist minorities that were left without any external 'protection' on the 'abandoned' territories of the former Ottoman Empire. Such attitudes towards 'guardianship' over the Muslim minorities were transformed into a real policy 
at the end of the Cold War and during the disintegration of former Yugoslavia. They were strongly manifested during the crisis in Bosnia (1992-1995).

Apart from Turgut Özal, Necmettin Erbakan also played a serious role in the 'advance' of neo-Ottomanism. In 1983, he set up the Welfare Party that took a firm stand on the ideological platform of Islamism. During the general election in 1995, this party won 21 per cent of the votes and Erbakan became prime minister. Yet during the following year the military forced him to tender his resignation. It was in this party that Recep Erdogan started his career as a politician. He followed Erbakan's path - he was dismissed from the post of mayor of Istanbul, faced charges in court and convicted, and ultimately sent to prison. He established the Justice and Development Party, through which he came to power. In 2001, the book 'Strategic Depth' written by his close aide Ahmet Davutoglu was published and it became the specific 'Bible' of neo-Ottomanism. Davutoglu started writing the book back in the mid-1990s, when he was lecturer at the university. He was not commissioned by those in power to write this book, but he worked on it together with researchers, intelligence agents and in close cooperation with the then Foreign Minister Abdullah Gul (president in 2007-2014). Davutoglu's prime motive involved his willingness to raise the efficiency of Turkey's foreign policy. As a result he developed a new concept for Turkey's foreign policy in line with the changes in global affairs and the country's domestic policy developments. Davutoglu was first appointed minister of foreign affairs in Erdogan's government. When Erdogan became president, Davutoglu took up the post of prime minister. Erdogan and Davutoglu had drawn lessons from their predecessors' 'bitter' experience, so the two leaders started gradually restricting the powers of the supreme military, replacing them with officers that were loyal to them. Top military officials were brought to court. After the attempted coup inspired by the US AngloSaxon and Jewish elites, a mass-scale purge was carried out in the army, the judiciary, the system of education, among other sectors. Neo-Ottomanism gained ground as an official state policy. What are its typical characteristics?

\section{THE DIMENSIONS OF NEO-OTTOMANISM} AS STATE POLICY

First. Over the past decade, there has been a radical shift in the Republic of Turkey's policy from Kemalism to Islamism. We have witnessed a coercive collaboration in which Recep Erdogan's concept of 
Islamist Ottomanism was incorporated within Kemal Ataturk's doctrine of secular Ottomanism, whereby the constitutionally prescribed civil rights were subjected to considerable amendments, which determined the sustainable re-Islamization of modern-day Turkey. For the sake of an objective assessment, it should be admitted that almost a century after the Kemalist revolution took place and Turkey was transformed into a secular state, the Turkish society has become a breeding ground for Islam. Neo-Ottomanism and Islamism have been combined in an explosive mixture. The erosion of the secular state has been performed in a systematic and consistent manner under the disguise of seemingly upholding the cult to the 'father of the Turks', as Ataturk is commonly referred to.

This stems from the innate controversies lying at the core of the two ideologies. Neo-Ottomanism is basically an imperial ideology, whereas Kemalism promoted the construction of the bourgeoisie nation. The latter is based on the aspirations toward the modernization of the Turkish society and the creation of the Turkish nation of a proWestern orientation. In essence Kemalism is the ideology of modernism that is not easily accepted by the Turkish society. This is what determines the deeply entrenched inferiority complex of the contemporary Turks who do not identify their society as a European one. Nevertheless they cherish the ambition to compete with Europe. It should be further noted that the Kemalists failed to establish a centralized economy, which lies at the basis of the countries that are catching up in their development. Neo-Ottomanism relies on an economic model that is based on the mechanisms of 'economic nationalism' that created the conditions for Turkey's economic prosperity. Undoubtedly, in social terms, the major factor for the emergence of neo-Ottomanism is Turkey's dynamic economic development over the past decades. Hence the pro-Islamist forces managed to establish their domination not only due to the prevalent ideological public attitudes, even though the latter is indisputably a crucial factor. As I. I. Starodubtsev argues in 'Turkey under transformation', 73 per cent of the followers of the Justice and Development Party supported the party because of the impressive economic achievements, and a mere 32 per cent of the voters did so for ideological considerations. For this reason, successful economic policy is essential to ensuring the voter support for the Justice and Development Party, outweighing the role of the party's political orientation toward Islam (Starodubtsev 2011: 75).

There are other symptoms of such public attitudes. In his comprehensive study Strategic Depth (Davutoglu 2015: 679), there are only 
three mentions of Ataturk! This naturally raises the question of whether Kemalism shows signs of re-Islamization. It does show such signs (independently from the differences in the institutional environment) considering that Kemal Ataturk's theory for the formation of the secular Turkish state severs the link between religion and state, but (national) identity remains intact. Neo-Ottomanism was conceived in the realm of Islam for two reasons. First, this religious basis allows the power holders in Ankara to resolve their domestic policy problems. Given the ethnic minorities comprising 18 million Kurds and a few million Alawites, presumably it would be difficult to achieve the integration of the Turkish community without the Muslim religion. Second, Erdogan uses Islam as a tool in his policy of restoring Turkey's influence in the Middle East. As becomes evident from the statements made by government officials in Ankara, Turkey had undeservedly suffered territorial losses in the Middle East. Therefore the power holders resorted to Islam in their attempts to unite the Muslims in this region.

Even though neo-Ottomanism undermines the fundaments of the secular state created by Kemal Ataturk, it nevertheless shares some common grounds with the Kemalist ideology. Among these values are patriotism and loyalty to the state. Both Kemalism and neo-Ottomanism are basically ideologies pertaining to the construction of the state. Hence neo-Ottomanism has much in common with the Kemalist nationalism, even though it is far more ambitious and idealistic in its projections of Turkey as a regional superpower (Taspinar 2008). It is well known that the Kemalists embraced the ideas of the Enlightenment, despite their claims that their actions are targeted mainly at defying the imperial ambitions of the big European countries. These assumptions are based on so-called 'Sevres complex' of the Turks, in which Europe's image is constructed as a power that jeopardizes Turkey's national unity. ${ }^{4}$ Regardless of the fact that many of Ataturk's reforms are pro-Western in character, Mustafa Kemal never assumed that the Kemalist revolution should involve a blind adoption and implementation of the European projects. Ataturk believes that the country's modernization should be analyzed within the universal paradigm typical of every nation aspiring toward finding its place in the contemporary world order. In this context, the Kemalist reforms are aimed at the construction of an independent and modern secular state rather than at a blind imitation of some nation in Western Europe.

Second - it is beyond any doubt that the neo-Ottomanist ideology contains some aspects of the contemporary revanchism. Neo-Ottomanism pinned its hopes on the revival of pan-Turkism. Based on the 
diachronic overview of this ideology's development, it can be conceded that, since it emerged in the early twentieth century, pan-Turkism has been aggressive and expansionary in nature. Hence it became the appropriate point of departure for neo-Ottomanism. It is evident that President Erdogan has been pursuing a policy that combines the elements of both neo-Ottomanism and pan-Turkism. Since the death of Kemal Ataturk, who imposed the doctrine of 'peace in the country, peace in the world', Turkey has never given up pan-Turkism. It was way back in the early 1930s that the country left the orbit of Kemalism. After the end of World War II, the country enjoyed the strong financial, military and political support of the United States, and as a result became a geo-political factor. This is what Ahmet Davutoglu says in Strategic Depth in this respect: 'The Muslim minorities that succeeded the Ottoman state provide the basis of Turkey's political influence in the Balkans. The Turkish and Muslim ethnic minorities living on the territory of Bulgaria, Turkey and Macedonia, to mention just a few, are in turn an important element of Turkey's policy in the Balkans.' Further down, elaborating on the construction of Turkey's 'defense umbrella', Davutoglu notes: 'It is on such legal grounds that Turkey should make attempts at obtaining borders that would ensure its right to interfere in resolving the issues of the Muslim minorities in the Balkans, following the model of its military operation in Cyprus'. These words expose the openly declared ambitions of today's power holders in Ankara to create Grand Turkey, taking advantage of the ethnic minorities living in the Balkans.

Third - is neo-Ottomanism hampering Turkey's integration in the European family? The analysis of neo-Ottomanism shows that it is at odds with the ideas of European integration, which was materialized in the concept for the European Union. It is a well-known fact that, after the empire collapsed, the territory of Turkey comprises a mere 7 per cent of the territory of the Old Continent. Therefore it cannot be regarded as a European country in geographic terms. However, it is a big Muslim country. Not to mention the fact, even though officially Turkey is a parliamentary republic, there is an authoritarian regime in place, and a civil war is regularly re-fuelled. Hence the Turkish state can only look up to its historical past of an empire. Despite the increased manipulation of the media in the form of books, films, conferences, exhibitions, among other forms of influence, it is unlikely that the Balkan peoples would readily accept the return of the so-called 'Golden Ottoman Ages', considering that they still share a negative memory and that the Balkan lands are replete with gravestones. Hence, by embracing the 'stra- 
tegic depth' of neo-Ottomanism as a strategic choice, the political elite in Turkey is ruining its chances for accession to the European Union. On the other hand, the European Union is too narrow a place for the realization of Turkey's ambitions, at least the ones declared in official statements. After all, in the event of Turkey's EU accession, the Union will curb the influence of what was described as neo-Ottomanism and defy Turkey's ambitions for expanding its political influence in the short or long run.

Fourth. The doctrine and policy of neo-Ottomanism are subject to evolution and rectification in the context of the dynamically changing domestic and foreign policy environment. Despite their ideological similarity, a clear distinction should be made between Recep Erdogan's and Ahmet Davutoglu's versions of neo-Ottomanism. The two versions offer two formulas of neo-Ottomanism that do not fully overlap. Erdogan's version of neo-Ottomanism is far more focused on Turkey's national interests, which are not always in line with the US interests in the Middle East or in the Balkans. It is this discrepancy between Ankara's and Washington's geo-political interests that opens up the space in which the interests of Russia and Turkey overlap.

\section{CONCLUSION}

The key issue at stake is the prospects for the establishment of the new geo-political and geo-economic hub. To rephrase it, the question is whether the plans and ambitions of Turkey's neo-Ottoman elite are feasible in the context of the real developments in the desirable region the Balkans, the Middle East and North Africa, and perhaps in Turkey itself. In the name of objectivity, it should be admitted that, despite its overambitious scope, such a project is unfeasible. There are two assumptions in this respect. First, despite the indisputable progress that Turkey has made in its economic development over the past few years, the country does not yet have sufficient resources and expertise to become a geo-economic hub. Furthermore, Turkey has a limited technological base. Second, in geopolitical terms, 'security' can be the only factor for integration. In other words, a country can offer guarantees of 'security' or 'protection' against some danger/risk, and it will thus increase its 'attractiveness'. Yet the problem is that the countries that Turkey wants to integrate do not see Turkey as a source of security. Just the opposite - they see the country as a source of threats. The Turkish authorities have come up with official statements pertaining to their policy of 'zero problems' with closer or more distant neighbouring countries. Evidence to this is the attempts on the part of the 
Turkish authorities to bring to normal the relations with Armenia, including the case of the restoration of the Surp Hac monastery on Aghtamar Island. Nevertheless, there are considerations that make these countries be on the alert. Such a consideration is the fact that the ideological platform of the Justice and Development Party is based on the ideas and principles of Muslim Brotherhood. A number of experts see President Erdogan as the most influential politician in the world who professes the ideology of Muslim Brotherhood. ${ }^{5}$

Another case is the expansion of 'Turkey's energy' in south Bulgaria, where a considerable part of the ethnic Turkish and Muslim minority is living. Estimates show that it has reached 20 per cent of the country's total population, given the low birth rate among the Christian ethnic Bulgarians compared to the reproduction rate among the ethnic Turks, the Roma and the Pomaks. The birth rate has been declining, which is a trend that has been observed in both Greece and Serbia. What also provokes anxiety is the impressive boom in the construction of infrastructure on the territory of the former north Thrace, the administrative center of which is the town of Kurdzhali. This town has enjoyed preferable treatment in terms of its dynamic development compared to the other regions in Bulgaria. It is generally admitted that the Muslim minority is united in its actions and that it may possibly be used under some political circumstances to serve purposes that run counter to the traditional tolerance between ethnic Turks and Bulgarians.

Such developments cannot but raise concerns in Turkey's neighbouring states, especially considering that a merger and close bondage between Islamism and neo-Ottomanism has been registered. Ahmet Davutoglu's rhetorical question is sufficiently telling: 'What is this republic of Kemal Ataturk? It is just 90 years old? After all, Turkey is the successor of the Ottoman Empire that ruled over territories spanning a whole three continents'.

No matter how unfeasible neo-Ottomanism may be regarded, it is by no means a safe and harmless political construct explored only in academic circles. After all, the fact that it lacks positive aspects carries negative implications, especially with regard to its attempts at vandalizing a foreign statehood.

\section{NOTES}

${ }^{1}$ The nationalist ideology started crystallizing in 1919, when in the town of Havza, Kemal Ataturk, in his capacity of general inspector of the military forces, established the organization for the national struggle for liberation from the occupying forces. 
${ }^{2}$ The chain of events arising from the collapse of the USSR and of socialism in south-eastern Europe brought about the formation of globalization in the late twentieth and early twenty-first century in the form of 'American globalism'. This American 'version' of globalism gave rise to the assumption that in the twentyfirst century, the 'American leadership' needs the support of a network of proAmerican 'regional leaders', who in turn seek the support of the United States to maintain their role in regional hegemony.

${ }^{3}$ In his address to the Turkish public and the international community, delivered at the Mejlissa in Ankara, Erdogan accuses Israel of committing 'bloody massacre' and calls on the Jewish state to immediately end the inhuman blockade of the Gaza Strip. 'No one should dare put our patience to the test', Erdogan warns, making the vow that Turkey will defend to the end the humanitarian cause for lifting the three-year long blockade against the Palestinians living in the Gaza Strip.

${ }^{4}$ This refers to the so-called Treaty of Sevres (1920), which provides for the split of the Ottoman Empire.

${ }^{5}$ Muslim Brotherhood was set up back in 1928 in Egypt by one of the most prominent representatives of Islamist fundamentalism, Hassan al-Banna (19061949). The organization's name highlights the importance attached to the religionbased connection between its members and its mission to call on Muslims to establish a brotherhood. At a later stage, Muslim Brotherhood was split up into two major groups - an extremist orthodox one and a moderate one that seeks compromise with the authorities. Ultimately extremism took the upper hand and was represented by Sayyid Qutb, who was worshipped as the martyr of faith. During the two years he spent in the United States, he came across attitudes that he considered to be a death threat to Muslims. Qutb further developed Hassan al-Banna's ideas into a more radical direction and proclaimed that Islam's revival should be launched at his house, calling for a decisive struggle against ignorance. In his view, an Islamic government should be formed and should act as the instrument of Allah's governance. This holds for the revival of the Caliphate, where Sheriat will rule and the Koran will be the only constitution. At the start of the twenty-first century, Muslim Brotherhood was the only organized fundamentalist force having relevance as a political factor. Its actions against the power holders created difficulties to the ruling secular regimes and to the radical Islamist movements. In national parliaments the organization would hold heated debate and form alliances and coalitions. A case in point is the Muslim Brotherhood in Jordan, called the Front for Islamist Action. They were recognized by the royal institution and were even invited to take part in government. Egypt's President Hosni Mubarak admits to the fact that Muslim Brotherhood is 'a peaceful party that makes use only of the tools of democracy and dropped violence long ago'.

\section{REFERENCES}

Davutoglu, A. 2015. Strategic Depth. Turkey's Place in International Relations. Sofia. Original in Russian (Давутоглу А. Стратегическая глубина. Место Туриии в международных отношениях. София).

Fadeeva, I. L. 1985. Official Doctrines in the Ideology and Politics of the Ottoman Empire (Ottomanism-Pan-Islamism) at the End of the $19^{\text {th }}$ Century and the Beginning of the $20^{\text {th }}$ Century. Moscow. Original in Russian (Фадеева И. Л. 
Официальные доктрины в идеалогии и политике османской империи (османизм - панисламизм ) в конце 19 в. - начале 20 в. Москва).

Georgieva, Ts. 1999. Space and the Spaces of the Bulgarians in $15-17^{\text {th }}$ Centuries. Sofia. Original in Bulgarian (Georgieva Ts. Prostranstvo i prostranstva na bălgarite ( $X V$-XVII vek. Sofia: Lik).

Hakov, J. 2010. Turkey's History in the $20^{\text {th }}$ Century. Sofia. Original in Russian (Хаков Дж. История Туриии в ХХ в. София).

Naydenov, G. 2017. The Ideology of Neo-Ottomanism. International Scientific Conference 'Management and Engeneering'. Days of Science at Sofia, pp. 523-531. Sofia: TU Sofia). Original in Russian (Найденов Г. Идеология неоосманизм. Международная научная конференция «Управление и инженеринг» с. 523-531. София: ТУ).

Petrov, L. 2015. Neo-Ottomanism. The Republic of Turkey's New Geo-political Doctine. Sofia. Original in Russian (Петров Л. Неоосманизм. Новая геополитическая доктрина Туреикой Республики. София).

Starodubtsev, I. I. 2011. Turkey under Transformation. Moscow: Institute for the Middle East, Moscow State Institute of International Relations). Original in Russian (Стародубцев И. И. Трансформирующаяся Туриия. Москва: Институт Ближнего Востока, МГИМО).

Stoykovski, G. 2014. The Rise of the White Crescent. Sofia: Institute for Regional and International Researches. Original in Bulgarian

Tanaskovic, D. 2010. Neo-Ottomanism. Turkey's Return to the Balkans. Sofia: Vostok-Zapad. Original in Bulgarian (Танаскович Д. Неоосманизм: Туриия возвращзается на Балканы. София: Изток-Запад).

Taspinar, O. 2008. Turkey's Middle East Policies: Between Neo-Ottomanism and Kemalism. URL: http://carnegieendowment.org/files/cmec10_taspinarfinal.pdf. 